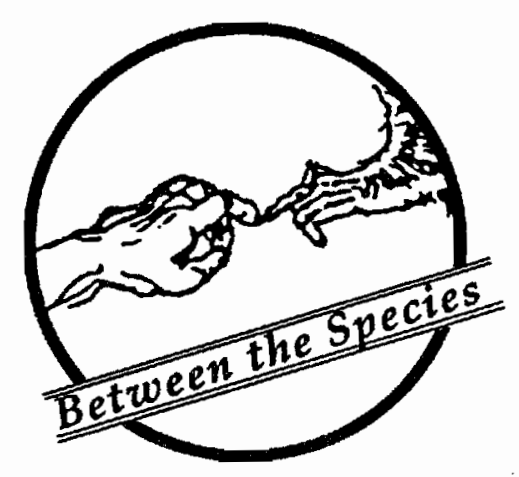

\title{
Jewish Prayer Service World Week of Prayer for Animals
}

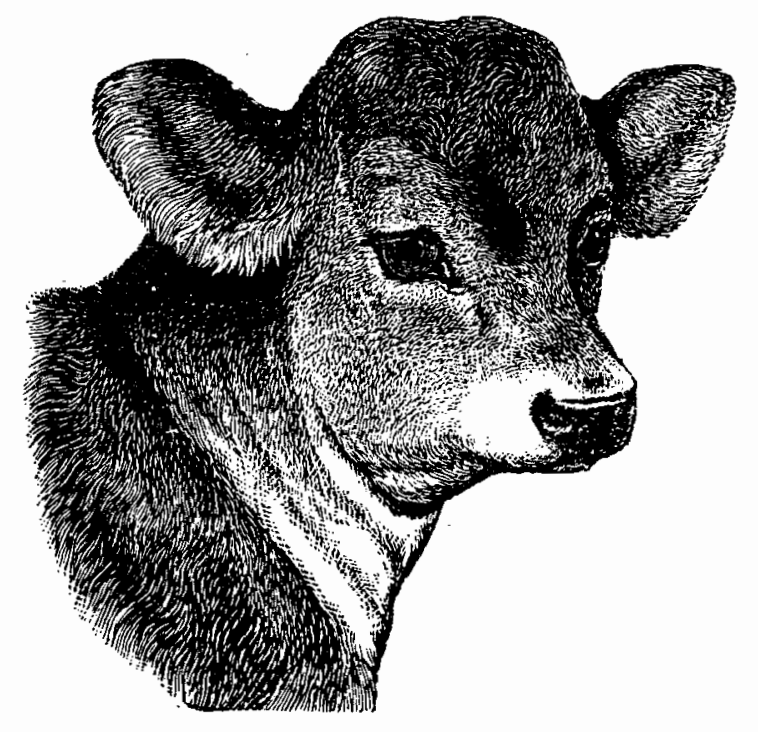

Rabbi Harold S. White

President, International Network for Religion and Animals

\section{Meditation and Reflection*}

$\sqrt{4}$

ternal God, Creator of all human life, parent of the universe, help us fulfill our obligation to replenish the world. Teach us the sanctity of all life that we may truly serve as partners with You in the daily act of creation. May we learn to manifest our love for You through loving all of Your Creation. May we become messengers of Your loving concern now and forever.

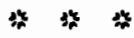

How wonderful, O God, are the works of Your hands! The heavens declare Your glory, the arch of sky displays Your handiwork.

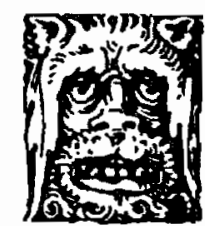

* Inspired by Psalm 104.

$R E \perp|G| O N$ 
In Your love You have given us the power to behold the beauty of Your world, robed in all its splendor. The sun and the stars, the valleys and hills, the rivers and lakes - all disclose Your presence.

The roaring breakers of the sea tell of Your awesome might; the beasts of the field and the birds of the air bespeak Your wondrous will. All life comes forth by Your creative will.

In Your goodness You have made us able to hear the music of the world. The raging of the winds, the whispering of trees in the wood, the precious voices of all created life reveal to us that You are in our midst. A divine voice sings through all creation.

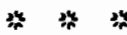

Of all created things the source is one,

Simple, single as love; remember

The cell and seed of life, the sphere

That is, of child, white bird, and small blue dragon-fly,

Green fern and the gold four-petalled tormentilla

The ultimate memory.

Each latent cell puts out a future,

Unfolds its differing complexity

As a tree puts forth leaves, and spins a fate

Fern-traced, bird-feathered, or fish-scaled.

Moss spreads its green film on the moist peat,

The germ of dragon-fly pulses in to animation and takes wing

As the water-lily from the mud ascends on its ropy stem

To open a sweet white calyx to the sky.

Open our eyes, God, to all of these marvels.

May we proclaim with the Psalmist:

"This is the day which God has made. Let us rejoice and be glad thereon."

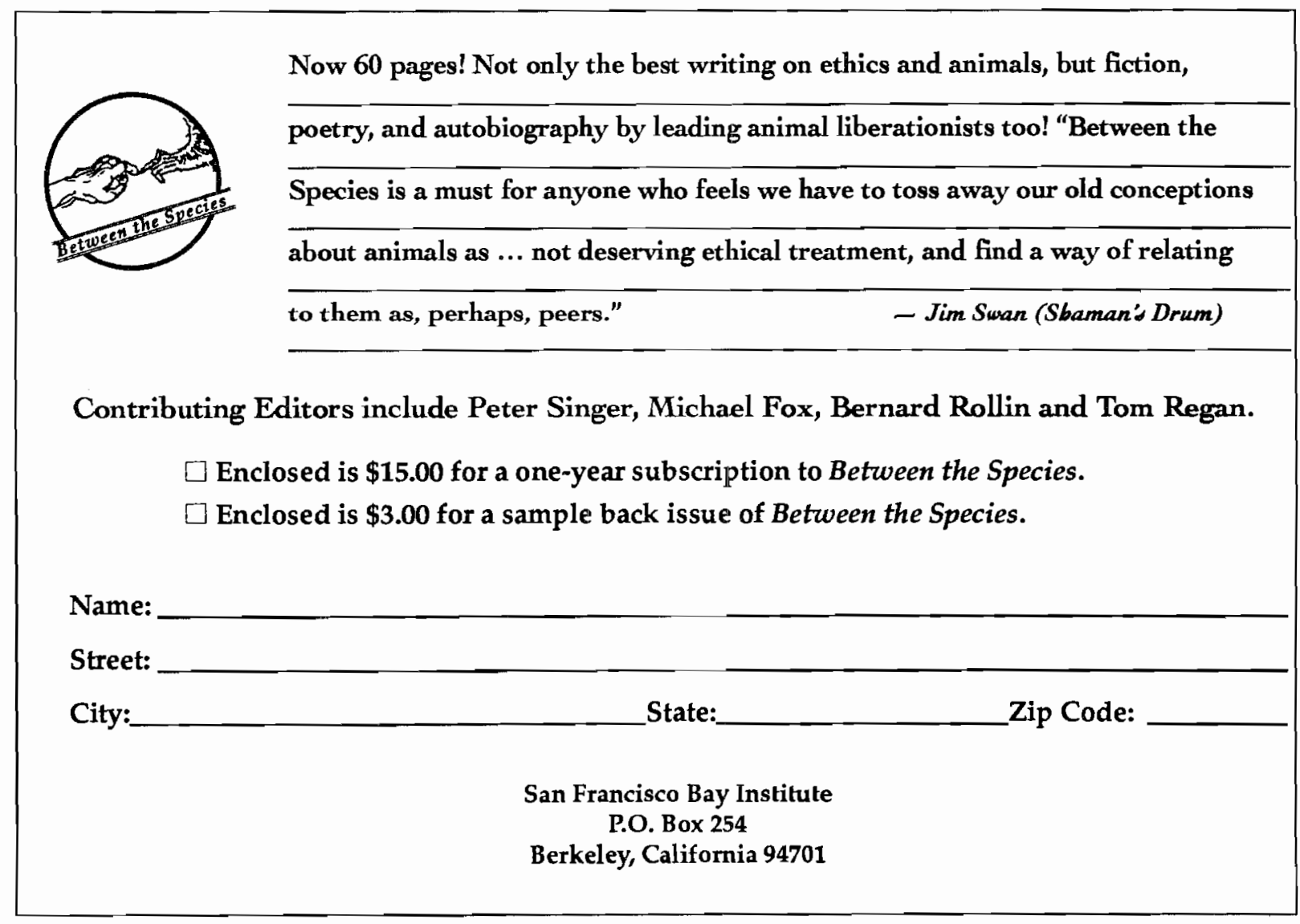

